ДО ПИТАННЯ ФОРМУВАННЯ ЗДОРОВ'ЯЗБЕРЕЖУВАЛЬНОЇ
КОМПЕТЕНТНОСТІ МАЙБУТНІХ УЧИТЕЛІВ ФІЗИЧНОЇ КУЛЬТУРИ

\title{
ON THE ISSUE OF THE FORMATION OF THE FUTURE PHYSICAL EDUCATION TEACHERS' HEALTH-PRESERVING COMPETENCE
}

Удк 378.147.091.31-051:796

DOI https://doi.org/10.32843/2663-

$6085 / 2021 / 35.15$

Гурін Р.C.,

канд. пед. наук, доцент, доцент кафедри педагогіки

Південноукраїнського національного педагогічного університету

імені К.Д. Ушинського

\section{Дроздова К.В.,}

канд. пед. наук,

старший викладач касредри теорії

і методики фрізичної культури та

спортивних дисциплін

Південноукраїнського національного

педагогічного університету

імені К.Д. Ушинського

Богатов A.O.,

викладач кафедри теорії і методики

фрізичної культури та спортивних дисциплін

Південноукраїнського національного педагогічного університету

імені К.Д. Ушинського
Статтю присвячено аналізу проблеми формування здоров'язбережувальної компетентності майбутніх учителів фрізичної культури під час професій̈ного становлення. Визначено, що збереження $i$ зміцнення здоров'я дітей $\epsilon$ насамперед пріоритетним напрямком безпеки життєдіяльності в суспільстві, що підтверджує значущість високого рівня сфрормованості здоров'язбережувальної компетентності як одного із найважливіших показників профресійного становлення майбутніх учителів фрізичної культури. Метою статmі $\epsilon$ теоретичне обгрунтування сутності конструкту «здоров'язбережувальна компетентність» та визначення особливостей ї̈ формування в майбутніх учителів фрізичної культури. Для реалізації мети було поставлено такі завдання дослідження: уточнити змістовне наповнення конструкту «здоров'язбережувальна компетентність» та експериментально перевірити залежність рівнів ії ссрормованості від індивідуальних характеристик майбутніх учителів фрізичної культури під час здобуття вищої освіти. у результаті аналізу психологопедагогічної літератури було встановлено, що здоров'язбережувальна компетентність учителя фрізичної культури охоплює: спрямованість особистості педагога; мотивацію до належного виконання просресійних обов'язків; професійні уміння; здатність до подолання стереотипів; готовність здійснювати здоров'язбережувальну діяльність; принциповість, здатність доводити задуми до завершення; самостійність, цілеспрямованість, вольові якості. Охарактеризовано такі шляхи формування здоров'язбережувальної компетентності майбутніх учителів фрізичної культури, як: соціальний, мотиваційний функціональний. Розглядаючи здоров'язбережувальну компетентність як цілісний системний конструкт, було встановлено, що на рівень ї̈ сформованості під час профресійного становлення суттєво впливають індивідуальні характеристики майбутніх учителів фрізичної культури, які можуть як сприяти, так і перешкоджати процесу ії фрормування.
Ключові слова: здоров'язбережувальна компетентність, моральні та вольові якості, толерантність, рефрлексивні уміння, емоційний інтелект, емоційна спрямованість.

The article analyzes the problem of the future physical education teachers' health-preserving competence formation during their professional development. It is determined that the preservation and improving of children's health is first and foremost a priority area of life safety in society, and it confirms that a high level of health-preserving competence can be one of the most important indicators of the future physical education teachers' professional development. The purpose of the article is to theoretically substantiate the essence of the construct "health-preserving competence" and determine the peculiarities of its formation in future physical education teachers. To achieve this goal, the following research objectives were set: to clarify the content of the construct "health-preserving competence" and experimentally verify the dependency of its formation levels on the future physical education teachers' individual characteristics during higher education. As a result of psychological and pedagogical literature analysis it was found out that health-preserving competence of a physical education teacher embraces: the orientation of the teacher's personality; motivation for the proper performance of professional duties; professional skills; ability to overcome the stereotypes; readiness to perform health-preserving activities; integrity, ability to implement the plans; independence, purposefulness, volitional qualities. The ways of forming the health-preserving competence of the future physical education teachers are characterized, namely: social, motivational and functional. Considering health-preserving competence as a holistic system construct, it was found out that the level of its formation during professional development is significantly influenced by the future physical education teachers' individual characteristics, which can both promote and impede its formation.

Key words: health-preserving competence, moral and volitional qualities, tolerance, reflexive skills, emotional intelligence, emotional orientation.
Постановка проблеми в загальному вигляді. Актуальність дослідження пов'язана 3 підготовкою конкурентоспроможних учителів фрізичної культури, що сприяє вирішенню Національної стратегії розвитку освіти в Україні на 2012-2021 рр., Концепції розвитку освіти в Україні на період 2015-2025 рр., Закону України «Про вищу освіту», проєкту «Нова українська школа», національної програ-ми «Здоров'я через освіту». Тому актуальності набуває подальший аналіз проблеми підготовки соціально активних і компетентних учителів фрізичної культури, здатних творчо діяти відповідно до навчальних завдань в освітніх установах різних рівнів акредитації, що підсилює увагу до їхньої індивідуальності; отже, високий рівень сорормованості здоров'язбережувальної компетентності $€$ одним із найважливіших показників професійного становлення.

Аналіз останніх досліджень і публікацій свідчить, що дослідниками переважно розглядаються особливості організації формування окремих складників здорового способу життя здобувачів вищої освіти, як-от: О. Гладощук, 2008 (Педагогічні умови вдосконалення культури зміцнення здоров'я студентів у системі фрізичного виховання у вищому навчальному закладі); Л. Дудорова, 2009 (Педагогічні умови фрормування потреби у здоровому способі життя майбутніх учи- 
телів у процесі фрізичного виховання); А. Конох, 2007 (Теоретичні та методичні засади професійної підготовки майбутніх фрахівців із спортивно-оздоровчого туризму у вищих навчальних закладах); І. Смолякова, 2010 (Формування здорового способу життя студентів у системі фрізичного виховання вищого технічного навчального закладу); О. Соколенко, 2008 (Формування ціннісного ставлення студентів вищих педагогічних навчальних закладів до свого здоров'я); Л. Соколенко, 2011 (Формування культури здорового способу життя студентів вищих навчальних закладів) та ін. Незважаючи на достатню кількість наукових досліджень, присвячених вивченню різноманітних аспектів підготовки майбутніх учителів фрізичної культури до профресійної діяльності, фрормуванню різновидів компетентностей та ціннісного ставлення до здоров'я (Н. Абаскалова, Н. Бірюков, Б. Братусь, Г. Глоба, І. Ільїна, Л. Євсеєв, М. Козуб, Г. Максименко, В. Наумчук, І. Омельяненко, О. Петунін, І. Поташнюк, О. Радіонова, М. Станкін, Б. Стасько, Л. Сущенко, Л. Татарнікова, Б. Шиян, І. Яковлєва, В. Яловик та ін.), питання цілеспрямованого фрормування їхньої здоров'язбережувальної компетентності залишається відкритим.

Виділення не вирішених раніше частин загальної проблеми. Підготовка сучасного вчителя фрізичної культури повинна враховувати відповідні компетентності, які необхідні для формування його особистості під час професійного становлення, та відповідати реаліям сьогодення. Попри наявність наукових розвідок із зазначеної проблематики, потребують подальшого вивчення теоретичні основи формування здоров'язбережувальної компетентності майбутніх учителів фрізичної культури. Підвищеної значущості набуває питання особливостей рормування здоров'язбережувальної компетентності майбутніх учителів фрізичної культури під час професійного становлення.

Мета статті полягає в теоретичному обґрунтуванні сутності конструкту «здоров'язбережувальна компетентність» тавизначенні особливостей ії фрормування в майбутніх учителів фрізичної культури.

Виклад основного матеріалу. Розглядаючи наукову категорію «компетентність» було встановлено, що багатогранність дослідження позначається на неоднозначності ії термінологічного оформлення. Вчені визначають цей контент як: реальний, чітко визначений, усвідомлений та реалізований на практиці комплекс професійних здатностей, готовності, знань, умінь та навичок, властивий конкретному представнику даної профресії, який включає в себе, попри інше, особистісне ставлення до предмету діяльності, самостійність, відповідальність та реалізується на практиці (С. Іваньшова, 2010); спосіб існування знань, умінь, освіченості, який сприяє особистісній самореалізації, знаходженню свого місця у світі, внаслідок чого освіта постає як високовмотивована й особистісно орієнтована і забезпечує максимальну витребуваність особистісного потенціалу, визнання особистості іншими, усвідомлення нею самою власної значущості (В. Болотов, 2004); комплекс професійних знань, умінь, відносин, професійних якостей особистості (С. Ніколаєва, 2003); інтегральна якість особистості, яка виявляється у здатності, що ґрунтується на знаннях і досвіді, набутих у процесі навчання і соціалізації та орієнтованих на самостійну й успішну участь у діяльності (Г. Селевко, 2004); складне, багаторівневе утворення особистості, яке характеризується теоретичною, практичною і психологічною їі підготовленістю до здійснення педагогічної діяльності відповідно до вимог і норм сучасності (Л. Шовкун, 2010). Ми цілком погоджуємося з дослідженням А. Петрова, в якому науковець розуміє під компетентністю категорію, що обумовлена рівнем професійної освіти, досвідом та індивідуальними здатностями педагога, і припускає, поряд 3 технолого-педагогічною готовністю до розв'язання професійних завдань, його гуманну педагогічну позицію, ціннісне ставлення до педагогічної діяльності й високий рівень загальної та професійної культури [6].

Зважаючи на те, що збереження і зміцнення здоров'я дітей $€$ насамперед пріоритетним напрямком безпеки життєдіяльності в суспільстві, набуває особливого значення фрормування здоров'язбережувальної компетентності майбутніх учителів фрізичної культури.

Аналіз наукового доробку сучасних учених (І. Іваній, С. Кодимський, А. Петров, Н. Сушик, Б. Шиян та ін.) довів, що здоров'язбережувальну компетентність визначають по-різному, а саме як: здатність активізувати, мобілізувати, ефективно застосувати інтегровану сукупність здоров'язбережувальних компетенцій у визначених умовах задля досягнення повного фрізичного, психічного, духовного, соціального благополуччя особистості [8, с. 180]; важливу складову професійно-педагогічної культури та узагальнений показник професійної компетентності, а також спосіб професійного самовдосконалення; необхідність підготовки висококваліфікованих кадрів, спроможних ефрективно реалізувати завдання формування, збереження і зміцнення здоров'я учнів; складну особистісну якість учителя, що регулює його діяльність у зазначеній сорері та забезпечує ефективність цього процесу; як систему інтегрованих властивостей особистості, адекватних структурі й змісту роботи щодо фрормування здорового способу життя підростаючого покоління [2, с. 219]. 3 іншого боку, ії фрормування відбувається на міжпредметному рівні за допомогою предметних компетенцій з урахуванням специфріки предметів та пізнавальних можливостей майбутніх учителів фрізичної культури, які мають змогу отримати висо- 
кий рівень знань і умінь для формування фрізично, духовно, інтелектуально і соціально здорової особистості дитини [1, с. 18; 3, с. 219; 11, с. 372].

Теоретичний аналіз означеної проблематики дав можливість встановити, що здоров'язбережувальна компетентність учителя фрізичної культури охоплює: спрямованість особистості педагога; мотивацію до належного виконання професійних обов'язків; професійні вміння; здатність до подолання стереотипів; готовність здійснювати здоров'язбережувальну діяльність; принциповість, здатність доводити задуми до завершення; самостійність, цілеспрямованість, вольові якості [6].

У розгляді шляхів формування здоров'язбережувальної компетентності майбутніх учителів фрізичної культури слушним є дослідження Г. Кондрацької, в якому авторка визначає такі, як: соціальний - здатність до співробітництва, взаєморозуміння, соціальної активності, фрормування фрізичної культури особистості, основ здорового способу життя; мотиваційний - фрормування особистісних уявлень про престижність високого рівня здоров'я та фрізичної підготовленості, здатність до навчання, творчий підхід до застосування рухових дій у різних умовах; функціональний - здатність до оперування знаннями про рухову активність, знаннями з історії фрізичної культури та спорту, розширення рухового досвіду та врахування компонентів професійної підготовки вчителя фрізичної культури (ціннісний, змістовий, діяльнісний). До умов ефективного фрормування здоров'язбережувальної компетентності авторка відносить: постійне мотивування до здорового способу життя і безпечної життєдіяльності; застосування інтерактивних технологій навчання, що забезпечують індивідуалізацію сприйняття, активну участь кожного здобувача вищої освіти групову взаємодію; переважання практичних дій і вправлянь у засвоєнні навчального матеріалу; забезпечення зв'язку між теоретичними відомостями й можливостями їх практичного застосування; організацію комунікативного спілкування, застосування в навчальному процесі ігрових методів, елементів дискусії, методу проєктів, які $є$ еорективними засобами розвитку здобувача вищої освіти, його громадянських якостей; ціннісне ставлення до свого здоров'я, особистого прикладу дотримання правил здорового і безпечного способу життя [6].

Проте, розглядаючи змістовне наповнення здоров'язбережувальної компетентності було встановлено, що на рівень її сформованості під час професійного становлення суттєво впливають індивідуальні характеристики майбутніх учителів фрізичної культури, які можуть як сприяти, так і перешкоджати процесу її формування. До таких індивідуальних характеристик (або чинників) відносимо: моральні та вольові якості, толерантність, рефлексивні уміння, емоційний інтелект, емоційну спрямованість.
3 метою визначення чинників, що впливають на рівні сфрормованості здоров'язбережувальної компетентності майбутніх учителів фрізичної культури, було здійснено емпіричне дослідження, під час якого вибірково було обрано та оцінено за ступенем прояву рівнів сформованості зазначеної компетентності 94 здобувача вищої освіти 1 і 2 року підготовки спеціальності 014 «Середня освіта (Фізична культура)» Інституту фрізичної культури, спорту та реабілітації державного закладу «Південноукраїнський національний педагогічний університет імені К. Д. Ушинського».

Так, з метою визначення рівнів сфрормованості моральних якостей майбутніх учителів фрізичної культури було здійснено діагностування за допомогою оцінної шкали прояву професійно-психологічних моральних якостей здобувачів вищої освіти (за Н. Кузьміною [4]). Сутність методики діагностики полягає у прояві 6 якостей особистості за двома основними групами якостей: професійноморальними та морально-психологічними. Відповіді у шкалі розташовані в порядку зростання: від 1 (відповідає оцінці «дуже погано») до 5 (оцінка «відмінно»). Відповідно, до низького рівня було віднесено респондентів, які отримали від 1,0 до 2,5 балів; до середнього - від 2,6 до 3,9 балів; до високого рівня - від 4,0 до 5,0 балів.

Для визначення сорормованості вольових якостей було використано методику оцінки вольових якостей О. Вострикова $[10$, с. 30-36] 3 деяким модифікуванням. Провідними вольовими якостями за означеною методикою $є$ цілеспрямованість, рішучість, сміливість, витриманість, самовладання, наполегливість, упертість, самостійність та ініціативність. Відповідно, до низького рівня було віднесено респондентів, що отримали від -3 до -2 балів, до середнього - від -1 до 0 балів, достатнього - від 0 до 1 балів, високого рівня - від 2 до 3 балів.

3 метою визначення рівня сорормованості толерантності майбутніх учителів фрізичної культури було використано методику діагностики комунікативної толерантності [9, с. 149-153], яка дозволяє виявити поведінкові ознаки толерантності особистості. Було обрано таку шкалу оцінки: 0-45 балів - низький рівень, 46-90 балів - середній рівень, 91-135 балів - високий рівень.

Сфрормованість рефлексивних умінь майбутніх учителів фрізичної культури діагностувалася за допомогою методики самооцінки рівня онтогенетичної рефрлексії, що передбачає аналіз минулих помилок, успішного та неуспішного досвіду життєдіяльності [9, с. 244-245]. Було обрано таку шкалу розподілу результатів: здобувачів вищої освіти, які набрали від 0 до 74 балів, було віднесено до таких, що мають низький рівень сформованості рефлексивних умінь, від 75 до 112 балів - середній рівень, від 113 до 150 балів - високий рівень відповідно. 
Результати діагностики чинників, що впливають на формування здоров'язбережувальної компетентності

\begin{tabular}{|l|c|c|c|}
\hline \multirow{2}{*}{\multicolumn{1}{c|}{ Чинники }} & \multicolumn{2}{|c|}{ Рівні сорормованості чинників у \% } \\
\cline { 2 - 4 } & високий & середній & низький \\
\hline Моральні якості & 15,3 & 41,8 & 32,9 \\
\hline Вольові якості & 14,2 & 52,5 & 32,3 \\
\hline Толерантність & 21,4 & 46,3 & 53,7 \\
\hline Рерлексивні уміння & 13,8 & 32,5 & 58,8 \\
\hline Емоційний інтелект & 5,4 & 35,8 & 28,1 \\
\hline Емоційна спрямованість & 18,5 & 53,4 & \\
\hline
\end{tabular}

Під час діагностики емоційного інтелекту було використано методику Д. Люсіна [5, с. 3-22]. В основу опитувальника покладено трактування емоційного інтелекту як здатності до розуміння своїх і чужих емоцій та управління ними. Здатність до розуміння емоцій означає, що людина: може виявити емоцію, тобто встановити сам фракт наявності емоційного переживання у себе або в іншої людини; може ідентифікувати емоцію, тобто встановити, яку саме емоцію відчуває вона сама або інша людина, і знайти для неї словесне вираження; розуміє причини, що викликали цю емоцію, і наслідки, до яких вона призведе.

Діагностика емоційної спрямованості майбутніх учителів фрізичної культури здійснювалася за допомогою тестового завдання, розробленого на підставі досліджень В. Семиченко [7, с. 42]. При цьому ми дотримувалися такої шкали оцінки: до високого рівня було віднесено тих респондентів, у яких емоційна спрямованість яскраво виражена, до середнього - помірно виражена, до низького - не виражена.

Результати діагностування рівнів ссрормованості означених чинників подано в таблиці 1.

Як бачимо 3 таблиці 1, здобувачі вищої освіти здебільшого перебували на низькому (42,9\% осіб від загальної кількості респондентів) та серед-

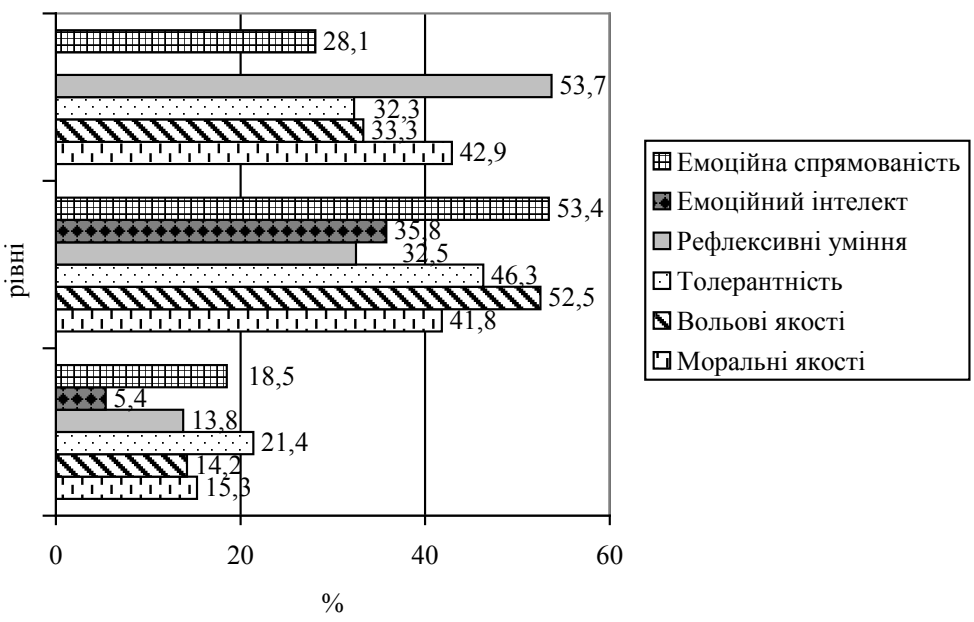

Рис. 1. Узагальнені результати сформованості чинників, що впливають на формування здоров'язбережувальної компетентності майбутніх учителів фрізичної культури ньому (41,8\% опитуваних) рівнях сорормованості професійно-психологічних якостей. Високий рівень виявили лише 15,3\% осіб від загальної кількості респондентів.

Одержані результати діагностики вольових якостей засвідчили, що на високому рівні перебували $14,2 \%$ респондентів , на середньому рівні $52,5 \%$ опитуваних, на низькому рівні - 33,3\% осіб від загальної кількості респондентів. Це свідчить про те, що майбутні вчителі фрізичної культури вміють витримувати напруженість, долати втому, домагатися виконання поставленого завдання. Проте вони не завжди доводять розпочату справу до кінця, не вміють керувати почуттями гніву, швидко знаходити потрібне рішення тощо.

Одержані результати діагностики комунікативної толерантності виявили, що більшість здобувачів вищої освіти перебували на середньому рівні $46,3 \%$ респондентів; на низькому рівні зафріксовано $32,3 \%$ осіб, тоді як на високому рівні - 21,4\% осіб від загальної кількості респондентів. Такі результати свідчать про те, що в цілому майбутні вчителі фрізичної культури досить терпляче ставляться до свого оточення, проте іноді виявляють дратівливість. Деяким із них складно приховати негативне ставлення до людей, які їм неприємні і т. ін.

Як свідчать дані таблиці, більшість респондентів $(53,7 \%$ осіб від загальної кількості опитуваних) перебували на низькому рівні ссрормованості рефлексивних умінь. Для цих здобувачів вищої освіти характерним $€$ острах перед здійсненням помилок, вони дуже обережні. На середньому рівні було зафріксовано 32,5\% респондентів; вони вміють аналізувати припущені помилки минулого досвіду, проте не завжди доходять відповідних висновків, але на достатньому рівні володіють умінням планувати свою діяльність, хоча відчувають складності щодо внесення відповідних коректив. На високому рівні було виявлено 13,8\% респондентів. Зазначені здобувачі вищої освіти вміють аналізувати минулий досвід і робити певні висновки. Ïм притаманні риси, якими володіють люди з високими здібностями до раціо- 
нального планування й передбачення власного майбутнього, вони є творцями власного життя.

Узагальнені результати, одержані під час дослідження, свідчать, що високий рівень емоційного інтелекту виявлено у 5,4\% респондентів. Більшість майбутніх учителів фрізичної культури продемонструвала переважно задовільний рівень - 58,8\% осіб. На низькому рівні діагностовано 35,8\% осіб від загальної кількості респондентів. Це ми пов'язуємо 3 відсутністю відповідних навчальних курсів, спрямованих на розвиток емоційного інтелекту майбутніх учителів під час профресійного становлення, що ставить під загрозу їхню здатність успішно та на високому рівні виконувати навчальні завдання.

Як свідчать дані таблиці, у більшості здобувачів вищої освіти емоційна спрямованість виявлена помірно (середній рівень) - 53,4\% респондентів; цей показник діагностовано на високому рівні у 18,5\% осіб від загальної кількості опитуваних. Низький рівень виявлено у 28,1\% респондентів. Зауважимо, що найбільші прояви мали альтруїстичні та романтичні емоції, найменше виявилися праксичні, акізитивні та гедоністичні емоції.

Узагальнені результати сорормованості чинників, що впливають на фрормування здоров'язбережувальної компетентності майбутніх учителів фрізичної культури, унаочнено на рисунку 1.

Отже, як видно з рисунку 1, найбільша кількість майбутніх учителів фрізичної культури засвідчила майже однакові середній та низький рівні сорормованості індивідуальних характеристик, що складає відповідно за середньоарифрмітичними значеннями 43,7\% та 41,5\% осіб від загальної кількості респондентів. На високому рівні сорормованості означених чинників, що впливають на формування здоров'язбережувальної компетентності майбутніх учителів фрізичної культури, опинилися лише 14,8\% осіб від загальної кількості опитуваних.

Одержані результати свідчать про недостатньо здійснювану цілеспрямовану роботу з майбутніми вчителями фрізичної культури під час занять, направлену на розвиток вищезазначених індивідуальних характеристик, а також роботу із забезпечення усвідомлення їхньої значущості у подальшому фрормуванні здоров'язбережувальної компетентності та професійно-педагогічній діяльності зокрема.

Висновки. Проведений аналіз теоретичного підґрунтя конструкту «здоров'язбережувальна компетентність» не вичерпує всіх аспектів означеної проблеми. Одержані результати свідчать про необхідність подальшого фрормування здоров'язбережувальної компетентності майбут- ніх учителів фрізичної культури в умовах університетської освіти. Саме тому перспективу подальших наукових розвідок убачаємо в розробці методики фрормування здоров'язбережувальної компетентності майбутніх учителів фрізичної культури під час профресійного становлення.

\section{БІБЛІОГРАФІЧНИЙ СПИСОК:}

1. Іваній І.В. Характеристика сутності здоров'язберігаючої компетентності вчителя фрізичної культури. Педагогіка, психологія та медикобіологічні проблеми фрізичного виховання і спорту. 2013. № 3 C. 18-22.

2. Кодимський С.С., Чайченко Н.Н. Педагогічні умови розвитку здоров'язбережувальної компетентності вчителів фрізичної культури в системі післядипломної педагогічної освіти. Педагогічні науки : теорія, історія, інноваційні технології. 2013. № 8. C. 217-224.

3. Кондрацька Г.Д. Шляхи фрормування здоров'язбережувальної компетентності у професійній підготовці майбутніх учителів фрізичної культури. International Academy Journal Web of Scholar 10 (28), Vol. 2, October - 2018, Warsaw, Poland, 2018. C. 14-18.

4. Кузьмина Н.В. Методы системного педагогического исследования. Ленинград : Изд во Лгу, 1980. $172 \mathrm{c}$.

5. Люсин Д.В. Новая методика для измерения эмоционального интеллекта : опросник ЭмИн. Психологическая диагностика. 2006. № 4. С. 3-22.

6. Петров А.О. Формування здоров'язбережувальної компетентності майбутніх учителів фрізичної культури в процесі професійної підготовки. Наукові записки Ніжинського державного університету ім. Миколи Гоголя. Психолого-педагогічні науки. 2014. № 1. С. 203-207.

7. Семиченко В.А. Психологія емоций. Київ : Магистр-S, 1999. 128 с.

8.СушикН.С. Формуванняздоров'язбережувальної компетентності особистості у реалізації технологій соціального виховання дітей підліткового та юнацького віку. Інноваційна педагогіка : науковий журнал. Одеса : Видавничий дім «Гельветика», Причорноморський науково-дослідний інститут економіки та інновацій, 2021. Вип. 32. Т. 1. С. 180-183.

9. Фетискин Н.П., Козлов В.В., Мануйлов Г.М. Социально-психологическая диагностика развития личности и малых групп. Москва : Изд-во Института Психотерапии, 2005. 490 с.

10. Формирование психологической устойчивости профрессиональной деятельности учителя как одной из характеристик человеческого фрактора : методические рекомендации / Р.И. Хмелюк, А.А. Востриков, Г.А. Нагорная, З.Н. Курлянд. Одесса : Одесский гос. пед. ин-т им. К.Д. Ушинского, 1986. 74 с.

11. Шиян Б.М. Підготовка вчителя фрізичної культури третього тисячоліття. Концепція розвитку галузі фрізичного виховання і спорту в Україні : зб. наук. пр. Рівне : Принт Хауз, 2001. Вип. 2. С. 371-374. 